\title{
Acknowledgments
}

This project, which began nearly ten years ago, has benefited at every stage from Cary Nelson's encouragement and incisive critique. Cary's political engagement, generosity, and commitment to his students have been an inspiration. Amanda Anderson, Michael Bérubé, and Robert Dale Parker were extraordinary readers. They saw potential in ideas that had yet to come to fruition and challenged my work in productive ways. Their comments resonate still. Rick Canning, Barry Faulk, Brady Harrison, Mary Hocks, and Lauren Onkey carefully read through very early draftswith a patience that could only emanate from friendship-giving me a wealth of insightful suggestions and helping me to work through many conflicting ideas. Bob McRuer and Sagri Dhairyam offered productive criticism of individual chapters. The members of University of Illinois' Feminist Theory Reading Group, especially Amanda Anderson, Janet Lyon, and Carol Neely, created an intellectual environment that helped shape my theoretical positions.

I am grateful to the Americanists here at the University of Texas at Arlington, especially Phil Cohen, Tim Morris, and Ken Roemer, for their interest in my work. I also thank Ken for reading one of my chapters and for a multitude of doorway discussions. Rajani Sudan sustains me with daily discussions of cultural studies and critical theory. Bruce Levy, of Southern Methodist University, generously shared his materials and ideas on Mary Austin. I also thank Ben Agger for his comments on this project and the College of Liberal Arts for a Faculty Development Leave that enabled me to complete my research. Thanks also to UTA's interlibrary loan office, especially Beatrice Cantu and Diana Hines, for providing me with a steady stream of materials.

Feminist Studies published an earlier version of the final chapter, entitled "Cyborg and Ecofeminist Interventions: Challenges for Environmental Feminism." Donna Haraway, a reader for that piece, gave me extensive and invaluable comments. Studies in American Fiction published a condensed version of the third chapter, "The Undomesticated Ground of Feminism: Mary Austin and the Progressive Women Conservationists." I am grateful to Melody Graulich for her rigorous reading of that essay. Many thanks to Barbara Kruger and the Estate of Ana Mendieta for allowing me to include their artwork and to Mary Boone Gallery and Galerie Lelong. I am quite grateful to the anonymous readers for Cornell University Press, especially the one who provoked me to add an entirely 
new chapter. Many thanks to my editors, Alison Shonkwiler and Catherine Rice, for transforming my manuscript into a book.

Finally, I'd like to thank my entire family for their support. The greatest thanks, however, go to Evan Engwall, who read and reread numerous drafts, helped me track down sources and illustrations, and gave generously of his wide-ranging knowledge and insight. Thank you, Evan, for enriching my life in every way. I dedicate this book to my daughter Emma, who helps me imagine feminist futures.

Stacy Alaimo

Dallas, Texas 


\section{Undomesticated Ground}


